\title{
Oxidizable carbon fractions in Red Latosol under different management systems ${ }^{1}$
}

\author{
Frações oxidáveis do carbono em Latossolo Vermelho sob diferentes sistemas de \\ manejo
}

\author{
Roni Fernandes Guareschi²*, Marcos Gervasio Pereira ${ }^{2}$ e Adriano Perin ${ }^{3}$
}

\begin{abstract}
The aim of this study was to evaluate the oxidizable fractions of organic $\mathrm{C}$ in a Red Latosol in an area of cerrado under a no-tillage system (NT) with different years of implantation, and to compare them to areas of native cerrado and pasture. The experimental design used was completely randomized with five replications. Treatments consisted of five areas: native cerrado (NC) "stricto sensu"; pasture (PA) planted with Brachiaria decumbens; NT with 3 (NT3); NT with 15 (NT15) and NT with 20 (NT20) years of implantation. There was an increase in the ground-surface mass of vegetable residue as a function of the time of implantation of the NT. An increase in C content and the carbon-management index (CMI) can be seen as a function of the time of implantation of the NT. In the area of NT20 the greatest values of C were quantified, compared to the area of cerrado. In general, there are increased labile and stable MOS fractions as a function of the implantation time of the NT, while the areas SPD15 and SPD20 present a C content among fractions, respectively similar and/or superior to the area of NC. Regardless of the area evaluated, a predominance of the more stable MOS fractions (F3+F4) can be seen. The area of PA, due to inadequate management, shows a more advanced stage of degradation when compared to the other areas, as there is a large reduction in the levels of total $\mathrm{C}$, of $\mathrm{C}$ in the more labile and stable MOS fractions, as well as lower CMI values.
\end{abstract}

Key words:No-tillage. Grassland. Soil organic matter. Labile carbon.

RESUMO - Objetivou-se com este trabalho avaliar as frações oxidáveis de C orgânico em um Latossolo Vermelho em área de cerrado sob sistema de plantio direto (SPD) com diferentes anos de implantação, e compará-las a áreas de cerrado nativo e pastagem. O delineamento utilizado foi inteiramente casualizado, com cinco repetições. Os tratamentos consistiram de cinco áreas: cerrado nativo (CE) "stricto sensu"; pastagem plantada (PA) com Brachiaria decumbens; SPD com 3 (SPD3); SPD com 15 (SPD15) e SPD com 20 (SPD20) anos de implantação. Foi observado aumento na massa dos resíduos vegetais da superfície do solo em função do tempo de implantação do SPD. Verifica-se aumento nos teores de C e no índice de manejo de carbono (IMC) em função do tempo de implantação do SPD. Na área de SPD20 quantificaram-se maiores valores de C em relação à área de cerrado. De maneira geral, verifica-se aumento das frações lábeis e estáveis da MOS em função do tempo de implantação do SPD, sendo que as áreas SPD15 e SPD20 apresentam teores de C dentre as frações semelhantes e/ou superiores respectivamente a área de $\mathrm{CE}$. Independentemente da área avaliada, observa-se que há predomínio das frações mais estáveis da MOS (F3+F4). A área de PA devido a um manejo inadequado apresenta-se em estádio de degradação mais avançado quando comparado às demais áreas, pois se observa uma grande redução dos teores de $\mathrm{C}$ total, $\mathrm{C}$ das frações mais lábeis e estáveis da MOS, bem como menores valores de IMC.

Palavras-chave: Plantio direto. Pastagem. Matéria orgânica do solo. Carbono lábil.

\footnotetext{
*Autor para correspondência

${ }^{1}$ Recebido para publicação em 20/08/2011; aprovado em 09/10/2012

Parte da Tese de Doutorado do primeiro autor defendida no Programa de Pós-Graduação em Agronomia, Ciência do Solo/UFRRJ

${ }^{2}$ Departamento de Solos, Universidade Federal Rural do Rio de Janeiro, Seropédica-RJ, Brasil, guareschiecotarelli@hotmail.com, mgervasiopereira01@gmail.com

${ }^{3}$ Departamento de Fitotecnia, Instituto Federal Goiano, Campus Rio Verde, Rio Verde-GO, Brasil, perinrj@yahoo.com.br
} 


\section{INTRODUCTION}

Theno-tillagesystem of farming(NTS)firstappeared in the cerrado in 1981 as an alternative to minimize the impacts caused to the soil by the different forms of usage. According to Carvalho et al. (2010) keeping plant residue (PR) on the surface, and not ploughing the soil, besides reducing the emission of $\mathrm{CO}_{2}$ into the atmosphere, also helps to increase the stock of $\mathrm{C}$ and $\mathrm{N}$ in the soil, bringing other benefits such as an increase in microbial diversity, and an improvement in the fertility and physical properties of the soil (FOLEY et al., 2005).

As well as the changes in the levels of organic matter in cultivated soils, there are also changes seen in the quality, and notably in the degree of oxidation and lability (SHANG; TIESSEN, 1997). Studies have shown that deforestation and cultivation of the soil, not only promote significant losses of carbon, but also contribute to the reduction of organic fractions of greater lability, generating an increase in the already high degree of aromaticity (SILVA; ANDERSON; VALE, 1999).

The different fractions of oxidation of $\mathrm{C}$ in the soil, proposed by Chan, Bowman and Oates (2001) are based on the separation of four fractions with decreasing degrees of oxidation, i.e. through the use of increasing concentrations of sulphuric acid the fractions, F1, F2, F3 and $\mathrm{F} 4$ are separated out. These correspond respectively to concentrations of $3 ; 6 ; 9$ and $12 \mathrm{~mol} \mathrm{~L}^{-1}$ of sulphuric acid.

The fractions F1 and F2 are associated with the availability of nutrients and the formation of macroaggregates (CHAN; BOWMAN; OATES, 2001), F1 is the fraction of greater lability in the soil, and highly correlated to the free light fraction of soil organic matter (SOM) (MAIA et al., 2007). The fractions F3 and F4 however, are related to compounds of greater chemical stability and higher molecular weight which originate from the decomposition and humification of the SOM. The fraction F4 is the most resistant in the soil, being called the "passive component" in simulation models of SOM (CHAN; BOWMAN; OATES, 2001).

Due to the scarcity of results regarding the effects of the adoption of NTS on the degree of oxidation of SOM, studies are necessary to assess the distribution of these fractions under this system, with the aim of demonstrating the impact of this type of interference on the activity of the ecosystem, and/or to determine the quality of soil in these areas in the medium and long term.

Starting from the above, the aim of this study was to evaluate the oxidisable fractions of soil organic $\mathrm{C}$ in grassland areas under a no-tillage system, and compare them to areas of native vegetation and pasture.

\section{MATERIAL AND METHODS}

The study was carried out at the Montividiu Tiuba Farm, in the municipality of Montividiu, in

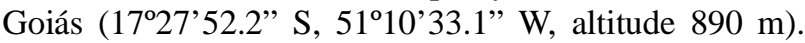
The average annual rainfall in the region is $1,740 \mathrm{~mm}$, with a warm tropical climate, classified as Aw by the Köppen system, and mainly flat terrain. The soils in the study areas have been classified as Red Distroferric Oxisols (EMPRESA BRASILEIRA DE PESQUISA AGROPECUÁRIA, 2006).

Four areas were analysed, namely: pasture with Brachiaria decumbens (PA); three years of NTS, with soybean cultivation in the summer and lying fallow for the rest of the year (NTS3); 15 years of NTS, rotating soybeans in the summer with maize or sorghum for the later harvest (NTS15); and 20 years of NTS, rotating soybeans in the summer with maize (NTS20). The experimental design was completely randomized with five replications. The plots consisted of four soil-management systems and one of strictly native cerrado (NC) used as reference.

With each management system, a representative area of $150 \times 150 \mathrm{~m}$, each in a similar position on the landscape were randomly chosen and marked out. In each area five trenches were dug with a surface area of approximately $1.0 \times 1.0 \mathrm{~m}$ and a depth of $1.0 \mathrm{~m}$, where undisturbed soil samples were collected employing a Kopeck ring (EMPRESA BRASILEIRA DE PESQUISA AGROPECUÁRIA, 1997) at depths of 0.0-0.05 m and 0.05-0.10 m. Samples of disturbed soil were also collected, which were then air dried, broken up and passed through a sieve of $2 \mathrm{~mm}$ mesh, resulting in a fine, airdried earth, which was used to characterize the chemical attributes of the soil and for particle-size analysis, following the Empresa Brasileira de Pesquisa Agropecuária (1997). The results of the characterization are given in Table 1.

The area of pasture with Brachiaria decumbens $\left(17^{\circ} 25^{\prime} 58.5^{\prime} \mathrm{S}, 5^{\circ} 09^{\prime} 39.4^{\prime} \mathrm{W}\right.$, altitude $\left.804 \mathrm{~m}\right)$, has been cultivated with approximately 1.5 animal unit per hectare. The area of NTS3 (17'27'20.9' S, 51'10'16.3" $\mathrm{W}$, altitude $858 \mathrm{~m}$ ) was established in 1987 with the removal of the cerrado. It was used for pasture for 20 years, after that rice was grown for 1 year, and 3 years ago NTS was adopted with soybean being cultivated. The area of NTS15

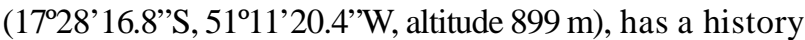
of 27 years of conventional tillage with soybean crops in the summer and maize in the winter, NTS being adopted

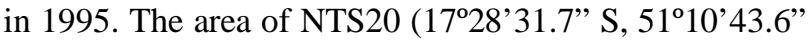
$\mathrm{W}$, altitude $898 \mathrm{~m}$ ) has had the same usage as the area of NTS15, however NTS was adopted in 1990. Currently, the areas of NTS15 and NTS20 are being planted with soybeans in the summer and maize or sorghum in the off-season. The cerrado being analysed is located 
Table 1 - Chemical attributes and particle size analysis in the areas of cerrado (CE), pasture (PA) and no-tillage system with 3 (NTS3), 15 (NTS15) and 20 (NTS20) years of usage

\begin{tabular}{|c|c|c|c|c|c|c|c|c|c|c|c|c|}
\hline \multirow{2}{*}{ Área } & \multirow{2}{*}{$\mathrm{pH} \mathrm{H} \mathrm{H}_{2} \mathrm{O}$} & \multirow{2}{*}{$\mathrm{P}^{*} \mathrm{mg} \mathrm{kg}{ }^{-1}$} & $\mathrm{Ca}$ & $\mathrm{Mg}$ & $\mathrm{K}^{+}$ & $\mathrm{Al}$ & $\mathrm{H}+\mathrm{Al}$ & $\mathrm{T}$ & $\mathrm{V}$ & Clay & Silt & Sand \\
\hline & & & \multicolumn{6}{|c|}{ - - } & $--\%--$ & \multicolumn{3}{|c|}{ 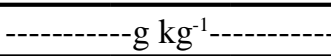 } \\
\hline & \multicolumn{12}{|c|}{$0-0.05 \mathrm{~m}$} \\
\hline $\mathrm{CE}$ & 4.4 & 9.5 & 8.0 & 19.0 & 2.0 & 5.0 & 133.0 & 162.0 & 17.8 & 410 & 170 & 420 \\
\hline PA & 5.7 & 2.1 & 39.0 & 47.0 & 2.0 & 0.0 & 73.0 & 163.0 & 54.6 & 600 & 190 & 210 \\
\hline NTS3 & 5 & 26.7 & 16.0 & 20.0 & 3.0 & 1.0 & 36.0 & 77.0 & 52.9 & 590 & 270 & 140 \\
\hline NTS15 & 5.0 & 33.6 & 26.0 & 29.0 & 3.0 & 1.0 & 46.0 & 106.0 & 56.4 & 630 & 170 & 200 \\
\hline \multirow[t]{2}{*}{ NTS20 } & & & 26.0 & 28.0 & 3.0 & 0.0 & 28.0 & 86.0 & 67.1 & 410 & 120 & 470 \\
\hline & \multicolumn{12}{|c|}{$0.05-0.10 \mathrm{~m}$} \\
\hline$\overline{\mathrm{CE}}$ & 3.0 & 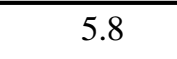 & 0.0 & 11.0 & 1.0 & 9.0 & 99.0 & 110.0 & 10.7 & 390 & 200 & 410 \\
\hline PA & 5.6 & 15 & 30.0 & 30.0 & 1.0 & 0.0 & 50.0 & 112.0 & 54.8 & 570 & 240 & 190 \\
\hline NTS3 & 5.1 & 20.9 & 9.0 & 17.0 & 3.0 & 1.0 & 38.0 & 66.0 & 42.0 & 610 & 270 & 120 \\
\hline NTS15 & 4.9 & 29.1 & 19.0 & 19.0 & 3.0 & 2.0 & 40.0 & 82.0 & 52.6 & 670 & 160 & 170 \\
\hline NTS20 & 5.3 & 29.2 & 18.0 & 18.0 & 3.0 & 1.0 & 39.0 & 79.0 & 50.3 & 460 & 110 & 430 \\
\hline
\end{tabular}

*P determined with a Mehlich extractor ${ }^{-1}$

inside the reserve area of the Montividiu Tiúba Farm (17²7'52.2" S, 51 ${ }^{\circ} 10^{\prime} 3.3$ " W, altitude $\left.890 \mathrm{~m}\right)$.

Basic fertilisation of the main crops of the agricultural systems were the following: 1) NTS3 and NTS15: a) soybean (summer), $458 \mathrm{~kg} \mathrm{ha}^{-1}$ of $02-20-20$ formula, b) maize (winter), $312 \mathrm{~kg} \mathrm{ha}^{-1}$ of 12-15-15 formula at sowing and $120 \mathrm{~kg} \mathrm{ha}^{-1}$ urea, as coverage at 25 DAE; 2) NTS20: a) soybean (summer) - $200 \mathrm{~kg} \mathrm{ha}^{-1}$ of 02-20-20 formula plus $60 \mathrm{~kg} \mathrm{ha}^{-1}$ of $\mathrm{K}_{2} \mathrm{O}$ and $\mathrm{P}_{2} \mathrm{O}_{5}$ as coverage, b) maize (winter), $30 \mathrm{~kg} \mathrm{ha}^{-1} \mathrm{~N}$ plus $60 \mathrm{~kg} \mathrm{ha}^{-1}$ $\mathrm{P}_{2} \mathrm{O}_{5}$ plus $70 \mathrm{~kg} \mathrm{ha}^{-1} \mathrm{~K}_{2} \mathrm{O}$ in the furrow and $120 \mathrm{~kg} \mathrm{ha}^{-1}$ urea as coverage at 25 DAE. NTS3 was treated with lime in 2006 and 2010, NTS15 was treated in 2007, and NTS20 in 2008. The area of PA received an application of $2 \mathrm{mg} \mathrm{ha}^{-1}$ of dolomitic limestone in 2009.

The amount of plant residue (PR) deposited on the soil surface in each study area was determined with the aid of a metal guage $\left(0.25 \mathrm{~m}^{2}\right)$ and subsequent collection of the PR. In each study area 20 samples were taken. The collected PR samples were dried in an oven under forced ventilation at a temperature of $65^{\circ} \mathrm{C}$ for 72 hours, and then weighed. From this data, the amount of dry mass of the surface PR was determined per hectare.

The $\mathrm{C}$ content was quantified by dry combustion using a CHNS analyzer. Fractionation of $\mathrm{C}$ by degrees of oxidation was also performed (CHAN; BOWMAN; OATES, 2001), four fractions with decreasing degrees of oxidation being obtained: a) Fraction $1(\mathrm{~F} 1)$ : C oxidized by $\mathrm{K}_{2} \mathrm{Cr}_{2} \mathrm{O}_{7}$ in an acid medium of $3 \mathrm{~mol} \mathrm{~L}^{-1} \mathrm{H}_{2} \mathrm{SO}_{4}$; b) Fraction 2 (F2): $\mathrm{C}$ difference oxidized by $\mathrm{K}_{2} \mathrm{Cr}_{2} \mathrm{O}_{7}$ in an acid medium of 6 and $3 \mathrm{~mol} \mathrm{~L}^{-1} \mathrm{H}_{2} \mathrm{SO}_{4}$; c) Fraction 3 (F3): C difference oxidized by $\mathrm{K}_{2} \mathrm{Cr}_{2} \mathrm{O}_{7}$ in an acid medium of 9 and $6 \mathrm{~mol} \mathrm{~L}^{-1}$ $\mathrm{H}_{2} \mathrm{SO}_{4}$; d) Fraction 4 (F4): C difference oxidized by $\mathrm{K}_{2} \mathrm{Cr}_{2} \mathrm{O}_{7}$ in an acid medium of 12 and $9 \mathrm{~mol} \mathrm{~L}^{-1} \mathrm{H}_{2} \mathrm{SO}_{4}$.

The $\mathrm{C}$ content in the $\mathrm{F} 1$ fraction was considered to be labile carbon $\left(\mathrm{C}_{\mathrm{L}}\right)$ of the soil (RANGEL et al., 2008), whereas the non-labile carbon $\left(\mathrm{C}_{\mathrm{NL}}\right)$ was determined by difference $\left(\mathrm{C}_{\mathrm{NL}}=\mathrm{C}-\mathrm{C}_{\mathrm{L}}\right)$. The percentage of total carbon $(\mathrm{C})$ of the soil was determined by dry combustion using a CHNS analyzer and then used to calculate the ratio $\mathrm{C}_{\mathrm{L}} / \mathrm{C}$, the Carbon Sharing Index (CSI). Based on changes in the $\mathrm{C}$ content of the soil in the reference area (of native vegetation) and of the soil under pasture and NTS, the following indices were calculated: $(\mathrm{CSI})=\mathrm{C}_{\text {cultivated }} / \mathrm{C}_{\text {reference }}$, Lability (L) $=\mathrm{C}_{\mathrm{L}} / \mathrm{C}_{\mathrm{NL}}$, Index of Lability $(\mathrm{IL})=\mathrm{L}_{\text {cultivated }} / \mathrm{L}_{\text {reference }}$ and Carbon Management Index $(\mathrm{CMI})=$ CCI x IL x 100, following Blair, Lefroy and Lisle (1995).

The results were evaluated using normality (Lilliefors) and homogeneity of error variances by the Cochran and Bartlett test. They were then subjected to variance analysis ( $\mathrm{F}$ test), and the mean values were compared by the Tukey test at $5 \%$ probability using the statistical software ASSISTAT.

\section{RESULTS AND DISCUSSION}

Of all the variables analyzed, only the ratio of labile $\mathrm{C}$ to total $\mathrm{C}$, lability, the carbon lability index $(0-0.05 \mathrm{~m})$ 
and fraction F2 $(0.05-0.10 \mathrm{~m})$ were not significantly affected $(\mathrm{p}<0.05)$ by the management systems (Table 2 ). The data showed a normal distribution and homogeneity of the variances. There was a statistical difference in the number of PRs deposited on the surface of the soil (Table 3).

The larger amount of PRS in the cerrado area is due to litter deposition, this area is also not subject to anthropic action. Similar results to this study were observed by Maman et al. (2007) when assessing the Cerradão Biome in southwestern Mato Grosso, where authors found yields of $9.5 \mathrm{Mg} \mathrm{ha}^{-1}$ of dry litter matter.
As for the areas of NTS, it can be seen that where this system has been installed for more time (15 and 20 years) more residue is produced, similar to that in the areas of 15 and 20 years and greater than in the area of NTS3.

When comparing areas of NTS with the area of cerrado, it appears that even in areas where NTS has been installed the longest ( 15 and 20 years), the production of residue was not sufficient to achieve those values quantified in the area of cerrado. The lesser residue production is attributed to the greater difficulty in establishing cover vegetation, due to the long periods

Table 2 - Summary of variance analysis, test for normality and homogeneity of variances for plant residues on the soil surface (1), total soil carbon (2), fraction F1 (3), F2 (4), F3 ( 5), F4 (6), non-labile carbon (7), ratio of labile C/C total (8), carbon component index (9), lability (10), lability index (11) and carbon management index (12)

\begin{tabular}{|c|c|c|c|c|c|c|c|c|c|c|c|c|c|}
\hline \multirow{4}{*}{ SV } & \multirow{4}{*}{ DF } & & & & & & & & & & & & \\
\hline & & 1 & 2 & 3 & 4 & 5 & 6 & 7 & 8 & 9 & 10 & 11 & 12 \\
\hline & & \multicolumn{12}{|c|}{ 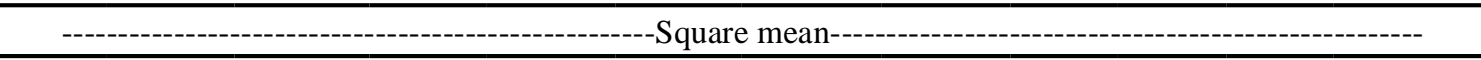 } \\
\hline & & \multicolumn{12}{|c|}{$0-0,05 \mathrm{~m}$} \\
\hline Trt & 4 & $4.0 * *$ & $92.5 * *$ & $14.0 * *$ & $3.6^{* *}$ & $21.1 * *$ & $20.3 * *$ & $134.5^{* *}$ & $9.8^{\mathrm{ns}}$ & $0.3 * *$ & $0.0^{\mathrm{ns}}$ & $0.0^{\mathrm{ns}}$ & $2957.3^{*}$ \\
\hline Res & 20 & 0.1 & 0.1 & 0.2 & 0.1 & 0.6 & 1.3 & 0.5 & 4.9 & 0.0 & 0.0 & 0.0 & 89.7 \\
\hline \multicolumn{2}{|c|}{$\mathrm{CV}(\%)$} & 4.2 & 3.1 & 8.6 & 16.8 & 11.4 & 12.0 & 3.8 & 9.2 & 3.7 & 12.1 & 15.3 & 12.6 \\
\hline \multicolumn{2}{|l|}{ Ks } & $0.6^{\mathrm{s}}$ & $0.2^{\mathrm{s}}$ & $0.2^{\mathrm{S}}$ & $0.2^{\mathrm{s}}$ & $0.1^{\mathrm{s}}$ & $0.2^{\mathrm{S}}$ & $0.3^{\mathrm{s}}$ & $0.1^{\mathrm{s}}$ & $0.3^{\mathrm{s}}$ & $0.1^{\mathrm{s}}$ & $0.1^{\mathrm{s}}$ & $0.1^{\mathrm{s}}$ \\
\hline \multicolumn{2}{|l|}{ Coch } & $0.5^{\mathrm{H}}$ & $0.4^{\mathrm{H}}$ & $0.4^{\mathrm{H}}$ & $0.4^{\mathrm{H}}$ & $0.4^{\mathrm{H}}$ & $0.4^{\mathrm{H}}$ & $0.3^{\mathrm{H}}$ & $0.4^{\mathrm{H}}$ & $0.5^{\mathrm{H}}$ & $0.5^{\mathrm{H}}$ & $0.4^{\mathrm{H}}$ & $0.3^{\mathrm{H}}$ \\
\hline & & \multicolumn{12}{|c|}{$0.05-0.10 \mathrm{~m}$} \\
\hline Trat & 4 & & $99.4 * *$ & $10.1 * *$ & $0.9^{\mathrm{ns}}$ & $8.5 * *$ & $16.2 * *$ & $165.9 * *$ & $60.6^{* *}$ & $0.1 * *$ & $0.0 * *$ & $0.3 * *$ & $4357.7 * *$ \\
\hline $\mathrm{R}$ & 20 & & 0.2 & 0.2 & 0.2 & 0.4 & 0.5 & 0.4 & 6.9 & 0.0 & 0.0 & 0.0 & 99.7 \\
\hline \multicolumn{2}{|c|}{$\mathrm{CV}(\%)$} & -- & 2.8 & 6.8 & 27.9 & 10.5 & 11.0 & 3.5 & 10.2 & 4.6 & 13.6 & 13.5 & 12.1 \\
\hline \multicolumn{2}{|l|}{$\mathrm{Ks}$} & & $0.2^{\mathrm{s}}$ & $0.1^{\mathrm{s}}$ & $0.2^{\mathrm{s}}$ & $0.1^{\mathrm{s}}$ & $0.2^{\mathrm{s}}$ & $0.2^{\mathrm{s}}$ & $0.1^{\mathrm{s}}$ & $0.3^{\mathrm{s}}$ & $0.1^{\mathrm{s}}$ & $0.2^{\mathrm{s}}$ & $0.2^{\mathrm{s}}$ \\
\hline \multicolumn{2}{|l|}{ Coch } & & $0.4^{\mathrm{H}}$ & $0.4^{\mathrm{H}}$ & $0.4^{\mathrm{H}}$ & $0.4^{\mathrm{H}}$ & $0.4^{\mathrm{H}}$ & $0.4^{\mathrm{H}}$ & $0.6^{\mathrm{H}}$ & $0.5^{\mathrm{H}}$ & $0.7^{\mathrm{H}}$ & $0.6^{\mathrm{H}}$ & $0.4^{\mathrm{H}}$ \\
\hline
\end{tabular}

SV - Source of variation; DF - degrees of freedom; Trt - treatments; Res - residue; Ks -Kolmogorov-Smirnov normality test; Coch - Cochran Test; **, * $\mathrm{e}^{\mathrm{ns}}$ - Significant to $1 \%, 5 \%$ e non-significant respectively by the $\mathrm{F}$ test,. $\mathrm{CV}(\%)$ - Coefficient of variation as a percentage; ${ }^{\mathrm{S}}$ - normal data distribution;

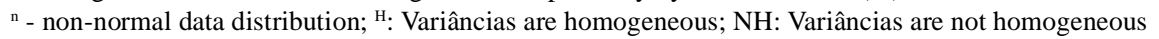

Table 3 - Plant residue deposited on the surface of the soil (PRS) in the areas assessed

\begin{tabular}{lc}
\hline \multicolumn{1}{c}{ Systems assessed } & PRS $\left(\mathrm{Mg} \mathrm{ha}^{-1}\right)$ \\
\hline CE & $10.07 \mathrm{a}^{*}$ \\
PA & $7.33 \mathrm{c}$ \\
NTS3 & $7.32 \mathrm{c}$ \\
NTS15 & $7.85 \mathrm{~b}$ \\
NTS20 & $8.65 \mathrm{~b}$ \\
\hline
\end{tabular}

*Averages when followed by the same lower case letter in any one column do not differ significantly across the different systems of soil usage by the Tukey test at $5 \%$ level of drought and the occurrence of dry spells (FIDELIS et al., 2003). The low production of residue in the area of pasture (PA) compared to the cerrado (EC), NTS15 and NTS20, is due to a combination of factors, such as low productivity, the absence of management systems (primarily of maintenance fertilization) and intensive grazing. According to the historical data of the area of PA, this has not received annual maintenance fertilization. According Zanine, Santos and Ferreira (2005) the lack of fertilization results in low productivity of the pasture. Table 4 shows the values of total soil carbon (C) in the evaluated crop systems. 
Table 4 - Total soil carbon (C) of the crop systems evaluated

\begin{tabular}{cccccc}
\hline & \multicolumn{5}{c}{ Systems evaluated } \\
\cline { 2 - 5 } Depth $(\mathrm{m})$ & $\mathrm{CE}$ & $\mathrm{PA}$ & $\mathrm{C}\left(\mathrm{g} \mathrm{kg}^{-1}\right)$ & $\mathrm{NTS} 15$ & NTS20 \\
\cline { 2 - 5 } & & & $15.97 \mathrm{c}$ & $29.66 \mathrm{~b}$ & $33.96 \mathrm{a}$ \\
\hline $0-0.05$ & $30.76 \mathrm{~b}^{*}$ & $15.45 \mathrm{c}$ & $15.43 \mathrm{c}$ & $27.12 \mathrm{~b}$ & $26.72 \mathrm{~b}$ \\
\hline
\end{tabular}

*Averages when followed by the same lower case letter in any one column do not differ significantly across the different systems of soil usage by the Tukey test at $5 \%$ level

In the layer at 0-0.05 $\mathrm{m}$, higher concentrations of $\mathrm{C}$ as a function time since NTS implantation can be seen, and in the area of NTS20, values of C and N greater than those observed in the field of $\mathrm{CE}$ are already being quantified. Also at this depth the area of NTS15 presents a $\mathrm{C}$ content similar to that found in the area of CE. These results show that the supply of materials of different quantities and qualities in the NTS contributes to an increase in the $\mathrm{C}$ and $\mathrm{N}$ content, which can be attributed to the higher rate of carbon addition to the soil, resulting from an increase in the primary productivity of the ecosystem promoted by less turning of the soil. Similar results were found by Matias et al. (2009) where the authors found that in areas of NTS in a Latosol in the region of Uruçuí in Piauí, there were increases in $\mathrm{C}$ levels relative to the areas of original cerrado.

In the layer at $0.05-0.10 \mathrm{~m}$, the area of CE showed the highest $\mathrm{C}$ and $\mathrm{N}$ content in relation to the other crop systems. The $\mathrm{C}$ content in the areas of NTS15 and NTS20 is similar and higher than the area of NTS3. According to Siqueira Neto et al. (2009) the cerradão presents larger amounts of carbon and nitrogen in the soil due to the continuous contribution of plant residues and the lack of disturbance to the system. In relation to the areas of NTS, an increase in the content of $\mathrm{C}$ and $\mathrm{N}$ as a function of time since implementation can be seen, but this increase is less significant than that observed in the surface layer (0-0.05 m).

One possible explanation for the low values of $\mathrm{C}$ in the area of NTS3 compared to the other crop systems, can be attributed to the short period since the system was adopted, as, according to Carvalho et al. (2009), the increase in SOM in the areas of NTS compared to other management systems may be related primarily to the time since implementation, because the accumulation of carbon in this system occurs very slowly, taking $10-15$ years to become significant. In contrast, the low levels of $\mathrm{C}$ in areas of PA may be related to their low productivity, the absence of management and intensive grazing, the small input of plant residue and also a reduction in root-system distribution. Silva et al. (2004) also found that pastures with low productivity in various regions of the cerrado favoured a reduction in the carbon content of the soil.
In the layers at $0-0.05$ and $0.05-0.10 \mathrm{~m}$ the $\mathrm{F} 1$ fraction (labile carbon) increased as a function of the time since implementation of the NTS, and that in the areas of NTS15 and NTS20 values of this fraction similar to those of the cerrado vegetation, and greater than in the area of PA (Table 5) are seen. The fraction F2 in the 0-0.05 m layer showed values similar to those discussed above for F1 however in the layer at $0.05-0.10 \mathrm{~m}$ no statistical differences were found between the areas assessed. From Table 5, one can also see that the fraction F3 at both of the depths analyzed also increased with the time since implementation of NTS, the values found in the area of NTS20 being greater than in the area of CE. As to the fraction $\mathrm{F} 4$, at both of the depths studied, the areas of NTS15, NTS20 and CE presented similar results being superior to those of the areas of PA and NTS3.

An increase of non-labile carbon $\left(\mathrm{C}_{\mathrm{NL}}\right)$ over the time since implantation of the NTS was found, with that of the area of NTS20 being greater than the other areas measured at a depth of 0 to $0.05 \mathrm{~m}$. However, in the $0.05-0.10 \mathrm{~m}$ layer, the area of $\mathrm{CE}$ presented the highest value of $\mathrm{C}_{\mathrm{NL}}$, followed by NTS15 and NTS20 which were similar, and higher than in the areas of PA and NTS3 (Table 5). Note also from Table 5 that there was no statistical difference between the areas evaluated for the proportion of labile carbon to total $\mathrm{C}\left(\mathrm{C}_{\mathrm{L}} / \mathrm{C}\right)$ at a depth of $0-0.05 \mathrm{~m}$, however at a depth of 0.05 to $0.10 \mathrm{~m}$ the area of NTS20 showed a higher proportion of $\mathrm{C}_{\mathrm{L}} / \mathrm{C}$ when compared to the other areas.

In a way similar to that observed for the levels of total $\mathrm{C}$, it is noted that in general the areas of PA and NTS3 presented the lowest concentration of $\mathrm{C}$ in relation to the other areas for the fractions F1, F2, F3 and F4 and $\mathrm{C}_{\mathrm{NL}}$. These results demonstrate that the area of PA is in a more advanced stage of degradation due to mishandling, which is a reflection of the type of management adopted, as when this is compared to the area of CE (reference vegetation), there is a large reduction in the $\mathrm{C}$ content of the more labile and stable fractions of the MOS. According to Rangel et al. (2008) this reduction in the content of total C in the soil, and the changes in the composition of the organic matter compromise the sustainability of the agro-ecosystem, 
Table 5 - Oxidizable fractions of organic carbon, non-labile carbon $\left(\mathrm{C}_{\mathrm{NL}}\right)$ and proportion of labile carbon / total C (CL/C) in different land use systems in Montividiu, Goiás

\begin{tabular}{|c|c|c|c|c|c|c|}
\hline \multirow{3}{*}{ Systems Evaluated } & \multicolumn{4}{|c|}{ Oxidisable fraction os carbon $\left(\mathrm{g} \mathrm{kg}^{-1}\right)$} & \multirow{2}{*}{$\mathrm{C}_{\mathrm{NL}}\left(\mathrm{g} \mathrm{kg}^{-1}\right)$} & \multirow{2}{*}{$\mathrm{C}_{\mathrm{L}} / \mathrm{C}(\%)$} \\
\hline & $\mathrm{F} 1\left(\mathrm{C}_{\mathrm{L}}\right)$ & $\mathrm{F} 2$ & F3 & $\mathrm{F} 4$ & & \\
\hline & \multicolumn{6}{|c|}{$0-0,05 \mathrm{~m}$} \\
\hline $\mathrm{CE}$ & $7.50 a b^{*}$ & $3.00 \mathrm{ab}$ & $6.66 \mathrm{~b}$ & $11.50 \mathrm{a}$ & $23.26 \mathrm{~b}$ & $24.37 \mathrm{a}$ \\
\hline PA & $3.83 \mathrm{c}$ & $1.16 \mathrm{c}$ & $4.00 \mathrm{c}$ & $6.33 \mathrm{~b}$ & $11.61 \mathrm{c}$ & $24.68 \mathrm{a}$ \\
\hline NTS3 & $3.83 \mathrm{c}$ & $1.00 \mathrm{c}$ & $4.16 \mathrm{c}$ & $6.66 \mathrm{~b}$ & $12.14 \mathrm{c}$ & $24.05 \mathrm{a}$ \\
\hline NTS15 & $6.16 \mathrm{~b}$ & $2.17 \mathrm{~b}$ & $7.83 \mathrm{~b}$ & $10.83 \mathrm{a}$ & $23.49 \mathrm{~b}$ & $20.79 \mathrm{a}$ \\
\hline \multirow[t]{2}{*}{ NTS20 } & $8.66 \mathrm{a}$ & $3.50 \mathrm{a}$ & $10.33 \mathrm{a}$ & $11.33 \mathrm{a}$ & $25.29 \mathrm{a}$ & $25.52 \mathrm{a}$ \\
\hline & \multicolumn{6}{|c|}{$0.05-0.10 \mathrm{~m}$} \\
\hline$\overline{\mathrm{CE}}$ & $8.83 \mathrm{ab}$ & $2.16 \mathrm{a}$ & $6.66 \mathrm{~b}$ & $9.16 \mathrm{a}$ & $28.56 \mathrm{a}$ & $20.78 \mathrm{~b}$ \\
\hline PA & $5.00 \mathrm{c}$ & $1.17 \mathrm{a}$ & $4.33 \mathrm{c}$ & $3.83 \mathrm{~b}$ & $10.25 \mathrm{c}$ & $27.14 \mathrm{~b}$ \\
\hline NTS3 & $5.16 \mathrm{c}$ & $1.17 \mathrm{a}$ & $4.66 \mathrm{c}$ & $4.33 \mathrm{~b}$ & $11.59 \mathrm{c}$ & $24.86 \mathrm{~b}$ \\
\hline BTS15 & $6.66 \mathrm{~b}$ & $1.50 \mathrm{a}$ & $6.33 \mathrm{~b}$ & $7.83 \mathrm{a}$ & $20.95 \mathrm{~b}$ & $22.75 \mathrm{~b}$ \\
\hline NTS20 & $8.66 \mathrm{a}$ & $2.33 \mathrm{a}$ & $8.50 \mathrm{a}$ & $7.50 \mathrm{a}$ & $18.05 \mathrm{~b}$ & $32.42 \mathrm{a}$ \\
\hline
\end{tabular}

*Averages when followed by the same lower case letter in any one column do not differ significantly across the different systems of soil usage by the Tukey test at $5 \%$ level

since the greater availability of organic compounds in the soil can increase the capacity of cationic exchange (PAVINATO; ROSOLEM, 2008), microbial activity (SCHERER; BALDISSERA; NESI, 2007), reduce the negative effects of toxic aluminum (CIOTTA et al., 2002; LIMA et al., 2007) and reduce the adsorption of phosphate groups onto colloids in the soil (SOUZA et al., 2006). The 20 years of PA which preceded the implementation of NTS in the area of NTS3, may be the reason for the similarity in the results observed for this area and in the area of PA (Table 5), since with the passage of the time of NTS implementation (NTS15 and NTS20) an increase in the $\mathrm{C}$ content of the fractions $\mathrm{F} 1, \mathrm{~F} 2, \mathrm{~F} 3, \mathrm{~F} 4$ and $\mathrm{C}_{\mathrm{NL}}$ can be seen. In some cases, the quantified values are similar to or even greater than those observed in the area of CE.

The increase of fractions F1 and F2 as a function of the time of implantation of the NTS, and the similarities observed between the areas NTS15 and NTS20 and the area of CE, occur due to the constant input under NTS of plant residue of various quantities and qualities to the surface of the soil, which over time promotes changes in the content and quality of the SOM. In studies on the fractionation of soil organic carbon Blair, Lefroy and Lisle (1995), Chan, Bowman and Oates (2001), Rangel et al. (2008) show that the highest levels of carbon in the fractions F1 and F2 tend to be found in areas where there is input of organic matter through plant residue, this increase being mainly related to the free light fraction of the SOM (MAIA et al., 2007).
From the results observed for fraction $F 1\left(C_{L}\right)$, the ability of this fraction to demonstrate the changes promoted by the evaluated management systems can be seen, this attribute therefore is of great importance in the assessment of soil quality in no-tillage areas as a function of its time since implementation. Similar results were found by Rangel et al. (2008), where the author notes that the $\mathrm{C}_{\mathrm{L}}$ showed greater potential to evaluate the impact of different planting densities and managements of coffee on the components of soil organic matter. Majumder et al. (2008) when assessing the fractions of oxidisable $\mathrm{C}$ in crop systems of rice and maize for 19 years in India, concluded that the F1 fractions can be considered a good indicator of the sustainability of the system, since they showed high correlation to the production of the corn and rice crops.

The F3 and F4 fractions increased from the area of NTS3 to that of NTS15, with values quantified in NTS15 being similar to those observed in the vegetation of the CE. From the above, it can be inferred that 15 years of NTS is the time required to return to the conditions found in the area of CE. This increase of the more recalcitrant fractions (F3 and F4) as a function of time since implementation of the NTS, may benefit from the maintenance of the mulch, less variation in moisture content and temperature, and the consequent creation of a favorable environment for the maintenance of SOM levels, with more stable fractions.

No significant differences were seen between the assessed areas for the percentage of $\mathrm{C}$ for the $\mathrm{F} 1+\mathrm{F} 2+\mathrm{F} 3+\mathrm{F} 4$ fractions with respect to the total $\mathrm{C}$, thus it can be said that 
regardless of the area and the depth evaluated, the fractions $(\mathrm{F} 3+\mathrm{F} 4)$ represent on average $66.4 \%$ of the total $\mathrm{C}$ in the soil, while fractions $(\mathrm{F} 1+\mathrm{F} 2)$ make up $33.6 \%$. These results indicate that under such conditions of soil and climate, the areas assessed present the greater part of the total $\mathrm{C}$ as being distributed over the F3 and F4 fractions, which are related to compounds of greater chemical stability and molecular weight, originating from the decomposition and humification of the SOM. Zech, Haumaier and Hempfling (1990) state that in tropical soils, the bioavailability of organic matter is naturally less, the presence of organic compounds rich in aromatic and carboxylic groupings being increased.

The highest levels of $\mathrm{C}_{\mathrm{NL}}$ from the area of NTS20 in relation to those from the $\mathrm{CE}$ show that there is a greater predominance of the more stable SOM fractions as a function of the NTS implementation time at a depth of 0-0.05 m. It can be considered that the increase in $\mathrm{C}_{\mathrm{NL}}$ is of great importance to the stability of the NTS, since the $\mathrm{C}$ of the non-labile fraction has a slower cycle compared to the labile $\mathrm{C}$, and acts both as a reserve of nutrients and in the chemical stabilization of microaggregates in the soil (ZECH et al. 1997).

At the depth of 0.05-0.10 m, the $\mathrm{C}_{\mathrm{NL}}$ and total $\mathrm{C}$ data were related where the area of $\mathrm{CE}$ presented higher contents of $\mathrm{C}_{\mathrm{NL}}$ and total $\mathrm{C}$ compared to other crop systems, and in the areas of NTS15 and NTS20 the $\mathrm{C}_{\mathrm{NL}}$ and total $\mathrm{C}$ are similar and greater than in the areas of NTS3 and PA. It can be inferred that the lower levels of $\mathrm{C}$ in the areas of NTS15 and NTS20 compared to those of the EC, may have caused the lower concentration of $\mathrm{C}_{\mathrm{NL}}$ in these areas at this depth. It can therefore be seen that at this depth, changes in the quantity and quality of the SOM, promoted by the NTS are not very significant, with no noteworthy differences being observed. It can be concluded that the $\mathrm{C}_{\mathrm{NL}}$ at a depth of $0.05-0.10 \mathrm{~m}$ has a higher resistance to changes due to the increased protection offered by the depth, greater changes only being verified when there are appreciable changes in the levels of total C. Bremer, Ellert and Janzen (1995) reported that changes in the $\mathrm{C}$ of the labile fraction, promoted by changes in soil management are seen within a short period of time, while in the non-labile fraction, changes in the $\mathrm{C}$ can only be observed in the long term.

The lack of any significant difference in data of the proportion of labile carbon to total $\mathrm{C}$ at a depth of 0-0.05 m demonstrates that the results of $\mathrm{C}_{\mathrm{L}}$ (oxidisable fraction $\mathrm{F} 1$ ) increase with the increase in total $\mathrm{C}$ content in each area evaluated, that is, each area has similar amounts of $\mathrm{C}_{\mathrm{L}}$ relative to its total $\mathrm{C}$ content. It appears that the levels of $\mathrm{C}_{\mathrm{L}}$ are more sensitive in showing modifications that the areas undergo. At a depth of $0.05-0.10 \mathrm{~m}$ the area of NTS20 presented a higher percentage for the ratio of labile carbon to total $\mathrm{C}$ in relation to all the other areas, that is, independent of the increase in total $\mathrm{C}$ content, the
$\mathrm{C}_{\mathrm{L}}$ tends to increase. In general, the percentage values of $\mathrm{C}_{\mathrm{L}}$ relative to total $\mathrm{C}$ were similar $(25 \%)$ to those found by Shang and Tiessen (1997) when evaluating the lability of $\mathrm{C}$ in an Oxisol of the Chapada do Araripe in Pernambuco, and that Rangel et al. (2008) found in a Red forest Oxisol in the region of Machado in Minas Gerais.

At both of the depths analysed, it can be seen that the carbon sharing index (CSI) and carbon management index (CMI) increased with the increasing implementation time of the NTS, and in the areas of NTS15 and NTS20 they were superior to those of NTS3 and PA (Table 6). Also using Table 6, it can be seen that there was no significant difference in lability or the lability index at a depth of 0-0.05 m.

The increase in CSI as a function of time since implementation of the NTS indicates that, in relation to the reference (CE), the NTS is contributing to the increase in levels of total $\mathrm{C}$, with a $\mathrm{C}$ content similar to that of the area of CE being reached at a depth of 0-0.05 $\mathrm{m}$ in the area of NTS20. The higher values of CSI in the areas of NTS15 and NTS20 can be attributed to the constant and greater input of plant residue on the soil surface, which over time has contributed to increased levels of SOM. However, the area of PA, due to its low productivity, absence of management, intensive grazing and the low input of plantresidue, showed lower CSI values, indicating that the levels of total $\mathrm{C}$ had been reduced, that is, the values of the CSI were smaller than 1 . Similar results were found by Rangel et al. (2008) when evaluating a typical Distroferric Red Latossol cultivated with coffee at different crop densities, in the south of Minas Gerais. The authors found that the highest and lowest CSI values were found in the areas where they saw respectively a higher and a lower accumulation of residue on the surface.

The results of $\mathrm{L}$ and IL have a correlation with the percentage of $\mathrm{C}_{\mathrm{L}}$ to $\mathrm{C}$ and $\mathrm{C}_{\mathrm{NL}}$ to $\mathrm{C}$ at both of the analysed depths. Because each area presents similar amounts of $C_{L}$ and $\mathrm{C}_{\mathrm{NL}}$ in relation to its content of total $\mathrm{C}$, and of these variables being used in the calculations of $\mathrm{L}$ and IL, there is a statistical similarity between the areas at a depth of 0-0.05 m. However, at the depth of $0.05-0.10 \mathrm{~m}$, the NTS20 area showed greater results of the ratio $C_{L}$ to $C$, $\mathrm{L}$ and IL compared to the others. This pattern shows that this area provides a less oxidative environment, giving greater physical protection to the SOM, favouring a higher proportion of labile $\mathrm{C}$ compared to total $\mathrm{C}$ by increasing the rate of C lability in the soil. Similarly Blair, Lefroy and Lisle (1995) found in soils in Australia that lack of disturbance of the soil by the NTS promotes a greater proportion of labile $\mathrm{C}$ and consequently a greater $\mathrm{C}$ lability.

The increase in CMI values as a function of the time since implementation of the NTS, which was observed at both depths in the area of NTS20, demonstrates that 
Table 6 - Carbon sharing index (CSI), lability (L), lability index (LI) and carbon management index (CMI), at depths of 0-0.05 and 0.05-0.10 m of a red latossol under different management systems in Montividíu, Goiás

\begin{tabular}{lcccc}
\hline \multirow{2}{*}{ Systems evaluated } & \multicolumn{5}{c}{ Indices } \\
\cline { 2 - 5 } & \multicolumn{5}{c}{ CSI } & L & IL & CMI \\
\cline { 2 - 5 } & \multicolumn{5}{c}{$0-0.05 \mathrm{~m}$} \\
\hline CE & -- & -- & -- \\
PA & $0.50 \mathrm{c}^{*}$ & $0.32 \mathrm{a}$ & $1.02 \mathrm{a}$ & $51.46 \mathrm{c}$ \\
NTS3 & $0.52 \mathrm{c}$ & $0.32 \mathrm{a}$ & $0.99 \mathrm{a}$ & $51.46 \mathrm{c}$ \\
NTS15 & $0.96 \mathrm{~b}$ & $0.26 \mathrm{a}$ & $0.82 \mathrm{a}$ & $78.52 \mathrm{~b}$ \\
NTS20 & $1.10 \mathrm{a}$ & $0.34 \mathrm{a}$ & $1.06 \mathrm{a}$ & $117.86 \mathrm{a}$ \\
\hline & & & $0.05-0.10 \mathrm{~m}$ & \\
\hline CE & ------- & $55.87 \mathrm{c}$ \\
PA & $0.39 \mathrm{~b}$ & $0.26 \mathrm{~b}$ & ---- & $54.42 \mathrm{c}$ \\
NTS3 & $0.43 \mathrm{~b}$ & $0.37 \mathrm{~b}$ & $1.43 \mathrm{~b}$ & $84.33 \mathrm{~b}$ \\
NTS15 & $0.33 \mathrm{~b}$ & $1.27 \mathrm{~b}$ & $135.95 \mathrm{a}$ \\
NTS20 & $0.75 \mathrm{a}$ & $0.29 \mathrm{~b}$ & $1.23 \mathrm{~b}$ & $1.83 \mathrm{a}$ \\
\hline
\end{tabular}

*Averages when followed by the same letter in any one column do not differ significantly across the different systems of soil usage by the Tukey test at $5 \%$

the management system employed in this area, together with no turning of the soil and the constant input of plant residue, has contributed to increase the capacity for preservation and restoration of the levels and/or the quality of the organic fractions. Rangel et al. (2008) when evaluating a Distroferric Red Latossol cultivated with coffee at different crop densities in southern Minas Gerais, also noted that higher CMI values were found in areas with greater amounts of coffee-crop residue (leaves and branches, among others) and a greater biomass of weeds.

The area of PA had the lowest CMI values, demonstrating once again that the type of management adopted is extremely detrimental to soil quality, leading to an advanced stage of soil degradation in this area.

\section{CONCLUSIONS}

1. An increase in the levels of the CMI and $\mathrm{C}$ can be seen as a function of the time since implementation of the NTS. In the area with 20 years NTS higher values of C relative to the area of cerrado were found;

2. In general, an increased in the labile and stable fractions of the SOM can be observed as a function of the time since implementation of the NTS, while the areas of NTS15 and NTS20 present a C content in the fractions, similar or superior respectively to those of the area of $\mathrm{CE}$;

3. Regardless of the area evaluated, a predominance of the more stable SOM fractions $(\mathrm{F} 3+\mathrm{F} 4)$ can be seen.

\section{REFERENCES}

BLAIR, G. J.; LEFROY, R. D. B.; LISLE, L. Soil carbon fractions based on their degree of oxidation, and the development of a carbon management index for agricultural systems. Australian Journal of Agricultural Research, v. 46, n. 7, p. 1459-1466, 1995.

BREMER, E.; ELLERT, B. H.; JANZEN, H. H. Total and light-fraction carbon dynamics durig four decades after cropping changes. Soil Science Society of America Journal, v. 59, n. 5, p. $1398-1403,1995$.

CARVALHO, J. L. N. et al. Carbon sequestration in agricultural soils in the Cerrado region of the Brazilian Amazon. Soil and Tillage Research, v. 103, n. 2, p. 342-349, 2009.

CARVALHO, J. L. N. et al. Potencial de sequestro de carbono em diferentes biomas do Brasil. Revista Brasileira de Ciência do Solo, v. 34, n. 2, p. 277-289, 2010.

CHAN, K. Y.; BOWMAN, A.; OATES, A. Oxidizible organic carbon fractions and soil quality changes in an Paleustalf under different pasture leys. Soil Science, v. 166, n. 1, p. 61-67, 2001.

CIOTTA, M. N. et al. Acidificação de um latossolo sob plantio direto. Revista Brasileira de Ciência do Solo, v. 26, n. 4, p. 1055-1064, 2002.

EMPRESA BRASILEIRA DE PESQUISA AGROPECUÁRIA. Sistema Brasileiro de Classificação de solos. 2. ed. Rio de Janeiro: EMBRAPA Solos, 2006. 306 p.

EMPRESA BRASILEIRA DE PESQUISA AGROPECUÁRIA. Manual de métodos de análise de solos. Rio de Janeiro: EMBRAPA Solos, 1997. 212 p.

FIDELIS, R. R. et al. Alguns aspectos para do plantio direto para a cultura da soja. Bioscience Journal, v. 19, n. 1, p. 23-31, 2003. 
FOLEY, J. A. et al. Global consequences of land use. Science, v. 309 , n. 5734 , p. $570-574,2005$.

LIMA, R. L. S. et al. Crescimento da mamoneira em solo com alto teor de alumínio na presença e ausência de matéria orgânica. Revista Brasileira de Oleaginosas e Fibrosas, v. 11, n. 1, p. 15-21, 2007.

MAIA, S. M. F. et al. Organic carbon pools in a Luvisol under agroforestry and conventional farming systems in the semi-arid region of Ceará, Brazil. Agroforestry Systems, v. 71, n. 2, p. 127-138, 2007.

MAJUMDER, B. et al. Organic amendments influence soil organic carbon pools and rice-wheat productivity. Soil Science Society of America journal, v. 72, n. 3, p. 775-785, 2008.

MAMAN, A. P. et al. Produção e acúmulo de serapilheira e decomposição foliar em mata de galeria e cerradão no sudoeste de mato grosso. Revista de Ciências Agro-Ambientais, v. 5, n. 1, p. 71-84, 2007.

MATIAS, M. C. B. S. et al. Biomassa microbiana e estoques de $\mathrm{C}$ e $\mathrm{N}$ do solo em diferentes sistemas de manejo, no Cerrado do Estado do Piauí. Acta Scientiarum, v. 31, n. 3, p. 517-521, 2009.

PAVINATO, P. S.; ROSOLEM, C. A. Disponibilidade de nutrientes no solo - decomposição e liberação de compostos orgânicos de resíduos vegetais. Revista Brasileira de Ciência do Solo, v. 32, n. 3, p. 911-920, 2008.

RANGEL, O. J. P. et al. Frações oxidáveis do carbono orgânico de Latossolo cultivado com cafeeiro em diferentes espaçamentos de plantio. Ciência e agrotecnologia, v. 32, n. 2, p. 429-437, 2008.

SHANG, C.; TIESSEN, H. Organic matter lability in a tropical oxisol: evidence from shifting cultivation, chemical oxidation, particle size, density and magnetic fractionations. Soil Science, v. 162 , n. 11, p. 795-807, 1997.

SCHERER, E. E.; BALDISSERA, I. T.; NESI, C. N. Propriedades químicas de um Latossolo Vermelho sob plantio direto e adubação com esterco de suínos. Revista Brasileira de Ciência do Solo, v. 31, n. 1, p. 123-131, 2007.

SILVA, C. A.; ANDERSON, S. J.; VALE, F. R. Carbono, nitrogênio e enxofre em frações granulométricas de dois Latossolos submetidos à calagem e adubação fosfatada. Revista Brasileira de Ciência do Solo, v. 23, n. 3, p. 593-602, 1999.

SILVA, J. E. et al. Carbon storage in clayey oxisol cultivated pastures in the "cerrado" region, Brazil. Agriculture, Ecosystem and Environment, v. 103, n. 2, p. 357-363, 2004.

SIQUEIRA NETO, M. et al. Carbono total e atributos químicos com diferentes usos do solo no Cerrado. Acta Scientiarum Agronomy, v. 31, n. 4, p. 709-717, 2009.

SOUZA, R. F. et al. Calagem e adubação orgânica: influência na adsorção de fósforo em solos. Revista Brasileira de Ciência do Solo, v. 30, n. 6, p. 975-983, 2006.

ZANINE, A. M.; SANTOS, E. M.; FERREIRA, D. J. Possíveis causas da degradação de pastagens. Revista Electronica de Veterinária, v. 6, n. 11, p. 1-23, 2005.

ZECH, W.; HAUMAIER, L.; HEMPFLING, R. Ecological aspects of soil organic matter in tropical land use. In: McCARTHY, P. et al. (Ed.). Humic substances in soil and crop sciences: selecting readings. Madison: ASA/SSSA, 1990. p. 187-220.

ZECH, W. et al. Factors controlling humification and mineralization of soil organic matter in the tropics. Geoderma, v. 79, n. 1-4, p. 117-161, 1997. 